\title{
EARLY TRANSPORTATION AND THE PLANK ROAD
}

\section{By Remley J. Glass}

The waterways of the Mississippi Valley furnished to Joliet, Marquette, La Salle, Hennepin, and Duluth a ready means of reaching the Father of Waters and the land we eall Iowa. "Ol River" and its tributaries furnished means of transportation which brought the later pioneers and explorers, Julien Dubuque, Louis Tesson, Basil Girard, and Jonathan Carver to settle on the west bank of the Mississippi. These waterways also furnished a ready means for the early explorations of Lieutenant Pike, for whom Pike's Peak near McGregor was named, and Lieutenant Albert Lea, after whom Albert Lea in Minnesota was named. And for centuries past these waters had earried the canoes and dugouts of Indian tribesmen in peace and war.

Along the river highways which poured into the Mississippi, the Wisconsin, the Des Moines, the Ohio, and the Missouriwater highways which furnished transport for explorers and discoverers - came the settlers and homesteaders who from Canada and the eastern seaboard sought that portion of the Louisiana Purehase which we now eall Iowa. Canoes, rafts, flat boats, keel boats, and river steamers all did their part in bringing settlers to the home of Blackhawk, Keokuk, and Poweshiek. But these modes of transport only brought them to the borders of the state to be.

The lack of roads and bridges coupled with the strength of the Indian tribes and their easily appreciated reluctance to sell their hunting grounds to a Great White Father whose solemn treaties were too often but "seraps of paper," to be disregarded under the urgent importunities of incoming settlers, had limited the early settlements to the banks of the Mississippi and the Des Moines rivers, with an occasional cabin

\footnotetext{
${ }^{1}$ In addition to drawing upon the resources of the State Historical Departments of Iowa, Illinois, Indiana, Ohio, Michigan, and New York, the other sources of information used besides those cited in the article were: John E. Brindley, History of Road Legislation, 1912: W. M. Gillespie, Road Making, 1871; Ira Osborn Baker, Road and Pavements, 1906; Charles E. Morrison, Highway Engineering, 1908; U. S. Patent Report, 1843, "Plank Roads in Canada" O Oliver W. Holmes, "Th: Turnpike Era," in the History of the State of New York, Vol. 5, 1934; Joseph Austin Durrenberger, Turnpikes, 1931.
} 
along the less navigable streams. Then too, because of geographic location and the geologic effect of glacial movement almost down to the dawn of history, while Iowa furnished the sources of the streams of the Mississippi Valley, it never afforded broad navigable streams up which eivilization might move easily and swiftly. Except for the Mississippi and the Missouri on its borders, and perhaps the Des Moines and the Iowa rivers in the southeastern part of the state, Iowa had no navigable streams. This had a direct effect upon the areas of settlement of the territory and of the state, as will be seen.

To show how closely connected water transportation and early settlements were, it is only necessary to examine the maps of Iowa published in the forties or fifties of the last century, when immigrants were moving into Iowa. A map published in Mitehell's Atlas of 1855 shows Keosauqua, Ottumwa, and Fort Des Moines located on the banks of the Des Moines River, one of the chief navigable streams of the state; on the Iowa River, Wapello, Marengo, and Iowa City, then the capitol of the state; on the Wapsipinicon, Anamosa; while Garnavillo and Fort Atkinson were on the Turkey River. Almost no other interior settlements appear.

The importance of the Iowa River, for instance, as a navigable stream then, and, as the pioneers viewed it, for the future, is shown in the provisions of the articles of incorporation of Iowa City, wherein the city is granted authority over river landings and permitted to control wharfage charges of various types of eraft docking there. ${ }^{2}$

Many years ago, during college days, I used to sit on the back porch of the home of Milton Remley in Iowa City and visit for hours with his father-in-law, Grandfather Dennis, one of those true pioneers beloved by old and young alike. He told of the old days and his experiences, how he had seen the Mormons journey westward, of the Push-Cart Expedition in 1856, and how, in his youth, he had watehed the river steamers land at the foot of Old Capitol Hill with bow and stern hawsers made fast to trees on the bank. Why is it that youth is so hasty and fails to realize the importance of those

${ }^{2}$ Acts of the Third General Assembly of Iowa, Chap. 43, sec. 28. 
chance told tales? What would I not give now to learn from him of those old days!

Viewing the Iowa River in 1938 one feels that these early steamers must have been of as shallow a draft as those which Mark Twain mentioned as running on a "heavy dew."

\section{Early Trails}

The development of the rich prairie regions of the interior back from the navigable water courses depended, therefore, upon the serviceability of Indian trails, 'traces,' game trails, and poorly marked immigrant roads.

It is difficult for us today to picture what those early settlers saw and experienced when they came west to establish themselves in the wilds of that portion of Wisconsin Territory west of the Mississippi which later became the State of Iowa. From tales handed down by word of mouth, we know something of how the settlers brought their families and household goods across the Mississippi and into Iowa. Oxen, mules, and horses dragged covered wagons up the gullies and ravines and along the ridge roads from Keokuk, Fort Madison, Dubuque, and the other river towns, into the interior counties so recently surrendered by unwilling Indian tribes. Slowly they dragged their way through timber, streams, and swamps and over prairies covered with native grasses until then marked only by the trails of Indians, trappers, and traders. Two or three miles a day was good progress even in the more settled areas. $^{3}$

By good fortune a record of such a pioneer journey has been left us by George C. Duffield, the journey made by James and Margaret Duffield and their seven children, of whom George was one, who eame from Fulton County, Illinois, to Iowa. In 1836 James Duffield had located the hometo-be in the unsurveyed timber land west of the Des Moines River in what is now Van Buren County, and in the spring of 1837 , while Iowa was still a part of the Territory of Wis-

\footnotetext{
3During the gold rush days of $1849-50$ it was advertised in several Iowa newspapers that "The distance from Iowa City to St. Fran-is [opnosite the river from Council Bluffs]. can be traveled in 12 days with ox teams. From Eddyville in 14 days." The first route passed through Newton and Fort Des Moines, the second was the southern route, straight west.
} 
consin, he brought his family and some of their stock and household goods on the westward trail. On March 9, 1837, they reached Appanoose on the eastern bank of the Mississippi, just across from Fort Madison. The following morning along with many other immigrants they were ferried into Iowa on a flat boat propelled by sweeps. The Duffields had a covered wagon drawn by a spike team composed of a yoke of oxen with a blind mare on the point. Shank's mares and a two-wheeled cart drawn by "Berry"' and "Bright," the second yoke of oxen, completed the transport. The first ox team had "Buck" and "Dick" as the pair, which was contrary to the usual nomenclature of ox teams which yoked "Buck" with "Bright.",

Up between the big bluffs, along the rude steep trail from the Mississippi to the prairie plateau above, the family slowly journeyed. Westward through West Point and on to Utica they traveled, then across the Des Moines River to the sive selected the year before by the father, James Duffield, on trails across virgin prairie, marked only by a few wheel tracks, that rainy Iowa March of 1837. A mile's progress was often the result of a day's painful effort. Wheels cut through the turf into the rich black soil. Teams bogged down, then wagons were unloaded, the whole family carrying the contents forward and returning to put their shoulders to the wheels.

With every passing group of settlers, however, such trails as these widened, for each immigrant wagon sought to avoid the mud hales caused by preceding vehicles by seeking a new and firmer foundation for wheels and animals. What had been a narrow buffalo trail or a single set of wheel tracks thus soon became a widely extended maze of ruts and quagmires. Experiences like that of the Duffield family were familiar to countless immigrant families who come to Iowa, "Beautiful Land," and furnished cogent reasons why the first sessions of territorial and state legislatures devoted so much of their time to road legislation.

The general interest in road improvement manifested by settlers and legislators may be likened to the demand of not

\footnotetext{
Annals of Iova, Third Series, VI, 1-9.
} 
so many years ago, when modern modes of transportation produced the popular ery, "Take Iowa Out of the Mud!" After reading the legislation of an earlier day, however, I am convinced that the modern ery was but a whisper compared. with the shouts heard by those prairie lawmakers. Those of us who ean recall the years before hard surfaced roads, when a spring journey in an automobile was not so different from the trip of James Duffield and his family, will not wonder that graded and plank roads were so enthusiastically welcomed by early Iowans.

That the river towns lacked the necessary roads and bridges to carry the immigrant population into the fat lands of the interior, and the roads and bridges to bring their produce to market was obvious. Trails and shallow fords which had been adequate for Indians and fur traders were not roads over which the settlers ceuld take their families and household goods and the paraphernalia of even a primitive civilization and transport grain and livestock to the existing markets, which of course was the very reason for their seeking homes in this prairie state.

Yet the "frontier" was never stationary-moving, or disappearing, with each new Indian treaty and with each year's influx of settlers. The next few years after the Duffields arrived, the frontier rapidly moved westward under the pressure of long trains of immigrant wagons journeying across Iowa in pursuit of homesteads and "Congress" land. After these early settlers had established themselves in their rude cabins, the desire for greater comforts which had been theirs in their eastern homes gave increasing importance to highways adequate to bring supplies of necessities and comforts, and adequate, also, to take out livestock, wheat, and timber with which to purchase those luxuries. Civilization demanded transportation. Each new year but increased the demand for roads to be built over prairies, for rude bridges to be established across the larger rivers.

The rapid increase of population in the forties and fifties tended to sharpen and focus the problem of highway facili- 
ties for the interior. The problem could not sleep with the immigrant horde continually pounding at the eastern borders of settlement for further admission. The increase of population along the Mississippi and the infiltration of settlers from eastern to western portions of the state was naturally an important factor in the discussion of early improved highway transportation.

The 1847 census returns for early Iowa show that Iowa's total population was 116,454 , distributed over thirty-two counties, mostly in the southeastern portion of the state. Centers of population were in the counties bordering on the Mississippi. Only Des Moines, Lee, and Van Buren counties boasted a total in excess of 10,000 , and Dallas County recorded but 164 white inhabitants.

Five years later, in 1852 , with seventeen additional counties reporting, the census total was 229,929 with five counties above the 10,000 figure with Dubuque and Jefferson counties added to the first three. Union County, however, could boast of but eighty eitizens.

In 1860 all but two of the counties of the State, Osceola and Lyon, show some white inhabitants with population trends apparent, tending toward the results we see today. The census total was 674,913 , with the river towns and counties still maintaining pre-eminence, but Polk, Marshall, Linn, Cedar, Blackhawk, and Allamakee and the agricultural counties were new centers of settlement. Prairies were beginning to attract settlers rather than timber lands along the creek and streams. Sod houses were taking the place of eabins. Wheat and grain assumed the importance held by minerals, wood, and livestock. Iowa was coming into her own.

Of necessity, this rapid advance was paralleled by an almost equally rapid advance in the laying out and improvement of interior communication lines for travel and freight. By 1860 the great experiment of Plank Roads had bloomed and died, the interior regions were dreaming deliriously of the coming of the Iron Horse which would open all the world to their trade, and the ghost of "inland navigation", had not yet been laid. But this was many years ahead. 
Today, as one journeys on the old immigrant highways from the river towns, every mile or two wide-porticoed houses come into view which old-timers inform us were taverns and inns where the newcomers then stopped for meals and rest as they sought their homesteads. It is sad that a modern Geoffrey Chaucer, tilted back in his chair against some tavern wall, while a haunch of venison turned on the spit and the Dutch oven gave forth savory odors, has not given us a record of the tales told around the fireplace, of Indian Chieftans in the full glory of beaded deer skin and eagle feathers, of the prototypes of Daniel Boone with hunting knife and long rifle ever seeking new lands, of immigrants in homespun pausing for the night, while oxen pastured and the mother and her flock of children, tired by the long day's journey, nodded over their suppers.

\section{The Early Roads and Commerce}

The demand for improved roads came not alone from the land hungry, culture seeking, settler of the interior. Each of the Iowa river towns, the then centers of population, regarded itself as an incipient St. Louis, and recognized that it must attract to itself settlers for the back country, and, what was equally important for them, must establish means for bringing the products which those settlers raised in the new country to town to exchange for goods from the eastern states found there. If this could not be done, each towns knew full well that its future would soon be but a past, as the frontier moved westward. Dubuque with its lead mines; MeGregor just across the river from Prairie du Chien; Bloomington (now Muscatine), Burlington, Fort Madison, and Keokuk were foci from which the entering wedge of settlement forced its way into Iowa. The early roads in Iowa naturally radiated from these points, linking one another, and extending vaguely towards the departing west; these aggressive "Empire" cities of the west were staunch ehampions of early highway improvement.

Although most of the early settlers were animated by the desire to own their farms and to establish themselves and their families in the rapidly developing west, they brought 
with them only the bare necessities of life. And although families were large, and the available and, of course, increasing manpower in each cabin made possible the utilization of the timber along the streams and the planting, eare, and harvesting of great amounts of corn, wheat, and other grains which the untapped fertility of these virgin plains produced so abundantly, nevertheless, the purchase and transport of supplies, the production and transport of goods required to procure such supplies was a necessity. Indian trails and game paths could not long suffice.

Though naturally Indian trails and game paths were utilized by the first road makers wherever possible, the needs of wagon transport imposed demands that trails blazed by the lone hunter and trapper, or the paths made by the migrating Indians could not meet. In laying their first roads, the early settlers often found it necessary to select the highlands, or ridges, to avoid streams with their spring and fall freshets, and swamps, and morasses. Many of the old trails in all parts of the state so laid out, twisting and turning to avoid these obstacles, were and are still known as "Ridge Roads." State Highway 13, from Strawberry Point to MeGregor, is a typical example. As you drive along, views of distant farmsteads and far-off valleys appear in infinite variety and one wonders what those old trail makers saw when they made their painful way among rocks and trees a hundred years ago.

Yet, despite spring freshets and fall rains which often made roads impassable, many of the early roads did wind their way up the valleys down which flowed the streams and rivulets. Along such courses the gradients were easy, and where the trails crossed the streams small bridges could be easily constructed, with corduroy roadways of branches and tree trunks filling mud holes and swamps. In the days of the slow oxen and the heavy cart an easy grade was some inducement indeed. Whether the route followed the ridges or the valleys, the wagon and harness makers of those early days must surely have known their trades, else not a single harness or wagon would have survived such strenuous usage as resulted from traveling those old highways. 
In the winter seasons wagons commonly gave place to sleds which traveled over the old roads or broke new paths across level unsettled areas. In the old days, when family reunions were important events, I have heard my father, John D. Glass, and my various uncles, tell of the long procession of sleds used in the winter season to carry wheatone of the few cash crops the settlers raised-from inland communities to points of shipment on the river, such as MeGregor, Dubuque, and Guttenburg. Each team or yoke took its turn at the head of the procession to break the road on those winter mornings, and from those stories we can imagine how, puffing and blowing, the lead team drew off to the side of the road, with clouds of steam rising from heaving flanks and distended nostrils, as the driver rested on his ox goad and exchanged salty comments with his fellows, striding along beside their teams in the deep snow.

The trails marked by these long trains of wagons or sleds, as concrete highways today, still curve and bend as if striving to find the easiest grade for slow moving oxen and creaking wagons.

\section{LEgISLATION FOR IMPROVED ROADS}

The need and the advantages of roads in the newly settled territory west of the Mississippi River was recognized by the legislature of the Territory of Wisconsin some four months before James Duffield and his family erossed to the lands of Iowa. The very first of the seventeen road enactments of the first Wisconsin territorial legislature, approved December 7, 1836, was the one providing for a "Territorial Road" in Iowa, ${ }^{5}$

commencing at Farmington on the Des Moines river, thenee to Moffit's mill, thence on the nearest and best route to Burlington, in Des Moines County, thence to Wapello, thence by the nearest and best route to the ferry opposite Prairie du Chien.

Two other territorial roads were authorized by the same legislature, one from Bloomington (Museatine) to Forty Mile Point on Cedar River, the other from Du Buque to Andrew Bank-

\footnotetext{
${ }^{5}$ Acts of the First Legislative Session of the Territory of Wisconsin, Chap. 20.
} 
ston's on the head waters of the Little Maquoketa. Significant of the times is the deseriptive clause which follows, "thence the nearest and best way to the settlement westward therefrom, in the county of Delaware. ",6

The widespread need for improved highways felt by the settlers who had struggled to reach their new homes, and each spring and fall struggled to bring in supplies and to take produce to market, was recognized by Robert Lucas, the first governor of the Territory of Iowa. In his first annual message to the legislature, in 1838, he said:

I would also recommend to your eonsideration the propriety of adopting a general road system, defining the manner of laying out and establishing Territorial and County roads, and to provide for opening and keeping them in repair.

Acting upon this recommendation and the urgency of the settlers, the Council and the House of Representatives in their first session adopted on December 29, 1838 " An Act as to laying out and opening Territorial Roads."

Spurred on by the need of transportation for the settlers, the demands of speculators of booming town sites, and not unmindful of the military advantages of good transport facilities, provision was made for a large number of highways under the Territorial Road system set out in the above act. It is safe to say, however, that only a few of the authorized roads were more than blazed trails or "paper" roads. "Even at best one could hardly eall such roads "improved" roads. Their inadequacy for commercial transport is indicated by the instructions given surveyors of "territorial" roads, which were

to be correctly surveyed and marked from the beginning throughout the whole distance, by setting stakes in the prairie at three hundred yards distance, and blazing trees in the timber. ...

Such roads, seventy feet in width, were to be maintained by the several counties through which they should pass. In those

'I Ibid., Chaps. 24, 25.

The Statute Laws of the Territory of Iowa, 1838-39, p. 429.

${ }^{8}$ During the eight years of Iowa's territorial existence, 186 chapters out of 950 placed on the statute books dealt with the highways, by enactment or amendment. This number looms larger when it is remembered that the first two sessions were mainly devoted to setting up the machinery for civil government. In 1846, 33 out of 123 chapters dealt with the road systems.-EpIror. 
days a county road tax, or road labor for a specified number of days per year, were the chief means of "maintenance" of the county roads.

Though the actual construction of improved highways seemed something far in the future, Iowa did not lack men of vision and initiative. A hundred years ago, in the First Territorial Assembly of Iowa, the legislators were approached by the "Burlington and Iowa River Turnpike Company" for a charter to build a graded turnpike from Burlington in Des Moines County, to proceed in a westerly direction to a point on the east bank of the Iowa River opposite the town of Blackhawk in Louisa County. A charter was granted the company on January 24, 1839. The capital was fixed at $\$ 100,000$, with shares of a par value of $\$ 25$. Organization of the eompany might proceed when $\$ 10,000$ had been subseribed. Toll rates were fixed, and to spur on the construction, it was provided that the company might charge one-half toll rates as soon as ten miles of the pike had been constructed. It was elearly the thought of the lawmakers that similar legislation would follow, as the act was expressly subject to "any general law that might be passed hereafter-for the regulation of Turnpike Companies."

After the establishment of Iowa in 1846 as the 29th state of the Union, highways were still eonsidered of paramount importance. How great that interest was is shown by the fact that 37 of the 125 chapters of the Acts of the First General Assembly had to do with speeific highways and of the 135 chapters of the Second General Assembly, a similar number, 37 , dealt with the same subject.

The number of these acts may be deceptive, however, for I am fearful that had an impartial investigator delved into the reasons and the expenditures for the ereation of these highways, he might have found that promises to constituents and the naming of well-paid commissioners, surveyors, and engineers to lay out the roads might have had considerable

The Statute Laws of the Territory of Iowa, 1838-39, np. 254-55. The Burlington and Des Moines Transportation Company was authorized on the same day to construct a canal, or a railroad or macadamized road if the canal proved infeasible. Laws of Territory of Iowa, pp. 255-63. 
influence with those early legislators. In fact, these pioneer lawmakers rewarded communities and extended patronage where it would do the most good, just as lawmakers, before and since, have done.

While Iowa was engaged in marking and widening a system of surveyed trails and roads, and making provisions for the beginning of an improved highway system under private hands, two new modes of transportation, in the meantime, were approaching the state from the east. As the late forties gave way to the fifties, the countryside thrilled with the expectancy of the coming of the Iron Horse, who was champing at the bit across the Mississippi, thinking enviously of the green pastures of every other section of land in a ten mile wide sweep along the right of way to be had across the river. Not quite lost in the mania of railroad construction that shortly seized the countryside was a brief yet significant experience with the transportation experiment Lord Sydenham brought to Canada in 1834-The Plank Road!

\section{Theories of Construction-The Plank Road}

In 1834, Charles Edward, Lord Sydenham, was sent to Canada as its Governor-General-his name appears in many places, including Corpus Juris, that compendium of legal lore, as Lord Lydenham. He brought to Canada information concerning plank roads which he had acquired during a long residence in Russia. Probably at his suggestion, or at least under his influence, in 1836 a few miles of plank road were laid near Toronto, the first of the new world. In that province the authorities had found macadamized roadways too expensive, both in original cost and annual upkeep, and, therefore, were most willing to follow the suggestions of Lord Sydenham.

Various methods of construction were tried out during the experimental stage in Canada and comparisons made of expense of construetion and upkeep with stone blocks and the system of crushed surfacing which had been evolved by the Scottish highway engineer, John L. McAdam. The early constructors of plank roads in Canada experimented extensively 
to evolve a satisfactory construction method. The timbers or sleepers upon which the planking was laid would vary in number from two to five. It was quickly determined that the joints should be staggered and that the sleepers should be firmly imbedded in the earth so that the planks might have earthen support across the highway, not only to avoid breaking, but to avoid dead air spaces which caused rapid decay. The planks themselves were first laid at an obtuse angle across the highway, which proved unsatisfactory, lengthwise, which also was undesirable, and at a right angle to the roadway, which gave the best results. They were spiked or pegged to the stringers to prevent turning or slipping. An eightfoot roadway was found most economical and advantageous.

The wear upon the planking was, of course, in the central portion of the roadway. From observation both in Canada and the United States, the first year's wear exceeded that of the next seven or eight because of the loosening of the surface fibers through sawing and the use of unseasoned wood. ${ }^{10}$

The men who organized the first plank road companies were in very truth like the sailors who accompanied Christopher Columbus, for they certainly journeyed over uncharted seas. Horsepower in those days meant what the grey mare and the roan gelding could pull when hitched to the lumber wagon. Gradients, highway drainage, banked curves, traffic eharts and the entire science of road building which we have at the office of the state highway engineer, were practically nonexistent in 1834. Highways were not far removed from Indian trails and deer paths.

Back in September, 1849, under the Indiana Plank Road Act, a plank road company was organized in Posey County, Indiana, with Robert Dale Owen, of New Harmony Community fame, as one of its directors. Although it was thirteen years after the first plank road was built in Canada, Owen realized his, and his fellow directors', abysmal ignorance of plank roads all too well, and began an investigation of highway problems and plank road construction in the Empire State where such roads had been in use for two or three

${ }^{10} U$. S. Senate Document 150, 28th Congress, 1st Session, Vol. 3. 
years. Fortunately, he embodied the information he gained in a thin, little sedecimo volume with the title Owen on Plank Roads embossed in gold on its cover. I would like to read its chapter headings to a modern highway engineer as he learnedly discusses drainage, exeavations, embankments and grades, and to show to a modern highway construction company the list of men and machinery which Owen deemed necessary. Twelve or fifteen men formed a crew in charge of a foreman, equipped with "a wooden roller composed of a butt end of a large burr oak," shovels, a "stout road plow of large size," a strong iron rake, and iron erowbar, a heavy wooden maul, a scraper requiring two horses and two men, "a stout ox cart and three or four good yoke of oxen." Two and one-half or three-inch planks sawed in eight-foot lengths were placed in convenient piles on one side with the stringers on the other, ready for the men to put them in place. Short lengths of plank were put under the joints of the stringers to avoid sinking during wet weather. Mr. Owen reckoned the cost of this lumber, "good and sound timber free from sap, bad knots, shakes, wanes and other imperfections impairing its strength and durability," at $\$ 7.00$ to $\$ 8.00$ per thousand board feet. The eight-foot strip of hemlock, pine, or oak planking, with yellow poplar on the steeper inclines to give the horses a surer footing, was laid on one side of the grade on stringers imbedded in the earth with additional sections every two hundred yards or so for turn-outs. With this equipment of men and machinery thirty or forty rods a day, or perhaps half a mile a week, allowing for rainy weather, could be constructed at a labor cost of about $\$ 200$ per mile.

The next time you stand on the curb and watch a modern paving machine with its attendant trucks and men, compare it with the work of the erews which laid plank roads up the hills from Burlington or along the Mississippi north of Keokuk ninety years ago-incidentally, too, compare the estimated cost of $\$ 938.08$ for material plus $\$ 200$ for labor per mile, aceording to Robert Dale Owen's reckoning, with $\$ 24,500$ for a mile of concrete roadway in 1937, according to figures in a letter from 
the Portland Cement Association. Yes, times have changed, and taxes likewise!

Refinements in construction appeared as the years passed. The fifteen or twenty-foot sleepers or stringers in many of the roads were $3 " \mathrm{x} 12^{\prime \prime}$, laid flat so as to distribute the burden on a wider base. They were laid at such a distance apart as to meet the requirements of the custom in reference to the distance between wheels of local vehicles. A heavier sleeper or stringer was usually placed on the outside edge of the road, not only to bear the additional burden, but also to act as the longitudinal support in case water made little channels under the sleepers. Twenty-foot grades were usual, the planked portion on one side, the balance being rolled and smoothed to form turn-outs if desired. The high point of the roadway was along the inside edge of the planking to insure proper drainage. The edges of the planks were not arranged in a straight line, but offset three or four inches every few feet to prevent the formation of ruts along the planking and also to make it easier for vehicles to regain their position on the planked highway if forced off. It was considered good practice to sand the planking so as to fill the interstices and harden the planked surface.

While the use of the plank road was able to reduce the tractive force required by about one-third, yet the selfish interest of the company often counteracted this possible result by failing to lower the grade of the road. This lessened the construction costs, and increased the number of loads farmers hauled, to the ultimate profit of the stockholders.

The question of fastening the planks to the roadway was one which was much discussed, and the best practice recommended that they be spiked at each end to the stringers.

Robert Owen also found that toll gates should be placed about six miles apart and his book shows designs for their construction. The toll gate keeper was required to open his gate for travelers at all hours of the day or night, ineluding Sunday, and to collect toll of all except "persons going to and from funerals and soldiers of the United States or State when in actual service." The usual rates were approximately those 
authorized in the articles of the Montrose-Keokuk Plank Road set out in this article.

Traffic was heavy in those days. On one roadway near Syracuse in New York state, it was estimated that eighty thousand teams passed in a year's time, or about two hundred twenty per day. We ean well understand that the hardworking toll-gate keepers received $\$ 10$ per month and free rent of the toll-house and adjacent garden spot!

\section{Early Plank Road Construction in the United States}

By the elose of the fourth decade in the new century, the turnpike system, which had played such an important part in the early development of this country, was seriously threatened by the competition of eanals and railroads. But in the succeeding forties and fifties the plank road, a new idea in highway construction brought from Russia via Canada, served temporarily to rejuvenate the well nigh moribund turnpike system.

The first plank road in the United States was constructed in 1845 and 1846 under the direction of George Geddes, between Syracuse, New York, and the foot of Oneida Lake, a distance of 14 miles. The new idea met with instant success both in New York and elsewhere in this country. Soon a flood of applieations for special charter plank road companies deluged the New York legislature, until the general plank road act was adopted on May 7, 1847. In the ensuing ten years three hundred fifty charters were granted, almost three thousand miles of plank road were built, and many millions of dollars invested in the plank road scheme.

The provisions of the New York law, which was the pattern for many of the other states which likewise experimented with plank road construction, required that stock to the amount of at least $\$ 500$ for each mile of proposed road must have been subscribed and at least five per cent of the subscription paid in cash before the articles of the company could be filed. The supervisors of the counties in or through which the road was to be constructed had to approve before work could commence. Stockholders were liable for an amount equal to their 
stock. Work on the project was required to be commenced within two years and completed within five.

Property rights of land owners, resident and non-resident, were adequately protected, particularly as to gardens, orchards, and homesteads, as were the rights of the state in navigable streams, and the investments of counties and townships and of existing turnpike companies in improved highways. Inspectors for turnpikes and plank roads were to be appointed in each county, but so far as the statutes show, they were not under civil service regulations, and perhaps in those barbarous days the jobs went to relatives and supporters of the county officers. ${ }^{\text {.1 }}$

Amendments to this act were made as experience determined their necessity. ${ }^{11}$

The New York Plank Road Act was the first such general law enacted in this country. Michigan was aetively interested in this type of highway; its act, modeled on that of New York, was adopted on March 13, 1848. Many miles were built in Indiana, which likewise formed its plank road legislation on the New York statute. The General Assembly of Indiana passed a general plank road act on January 15, 1849. The Indiana act, however, increased the amount of stock required to be subseribed from $\$ 500$ to $\$ 1500$ per mile before articles could be filed and organzation effected. Ohio found the new method of construction desirable too, and Illinois ambitiously constructed main lines and feeders. The general statute of Illinois was adopted on April 13, 1849, and its terms, which seems to have been based on that of New York, vested the control of the companies in the county court, however, rather than in the Board of Supervisors. ${ }^{12}$

The Wisconsin general plank road law was approved and signed on August 21, 1848; the first plank road, however, had been authorized February 2, 1846. By the year of the general enactment, eleven companies had been legally provided for. In the later Wisconsin acts, interestingly enough, certain companies were permitted to construet plank roads of "timber,

\footnotetext{
${ }^{11}$ Law of the Senate and Assembly of $N$ rw York, 1847, Chap. 210, 398; Laws of New York, 1848, Chap. 360: Lazes of New York, 1849, Chan. 250

12 Illinois Session Lawe, 1849, 1st Session, 16th G. A., Chap. 125.
} 
plank or other hard surface," the hard surface to be gravel, stone, or even chareoal. ${ }^{13}$

Minnesota's first plank road eompany was formed by act of the legislature of the territory, November 1, 1849. A liberal interpretation of what constitutes a plank road is also evidenced in the Minnesota legislation, for one plank road company was permitted to construct a road of which "the track of said road shall be constructed with rails, plank, stone, gravel, or the prairie or timber soil, or chareoal in whole or in part at the option of the directors, so that the same shall continue a firm and smooth surface for the passage of wagons and carriages." ${ }^{\prime \prime 4}$

Many of the old trails, such as "Zane's Trace" which Ebenezer Zane laid out from Wheeling (West) Virginia through Zanesville and Chillicothe to the Indiana line, long one of southern Ohio's ehief highways, were turnpiked. Most of the improved highways, constructed in Ohio in prerailroad days were built by turnpike companies, until 1843 , when the state was authorized to eonstruet free public turnpikes, finaneing the cost by taxes on all lands within two miles of the road. ${ }^{15}$

Since highway and other conditions in the neighboring state of Illinois were and are similar to those of Iowa, it will be profitable to glance more closely at the era of plank roads in that state. ${ }^{10}$

Illinois was the gateway to the great northwest, through whose eities and towns moved men and supplies in an endless stream to open up the west for settlement. Railroads were then only considered as vague possibilities, but rivers, canals, and most important of all, all-weather highways, were what were neeessary to direct and divert this most profitable business to and through rapidly developing centers of trade. Chicago, then as now, was a shipping and manu-

\footnotetext{
13 Laws of the Territory of Wisconsin, 1846, pn. 57-62: Laws of the State of Wisconsin, 1848, pp. 248.64: Laws of Wisconsin, 1850, Chap. 148, p. 119.

${ }^{14}$ Collated Statutes of the Territory of Minnesota, 1853, Chap. 12, pp. 59-63; Laws of Minnesota, 1854, Chap. 125, sec. 7.

${ }_{15}$ Report of the Survey of Transportation on the State Highway System of Ohio, 1927. It seems probable that had not the railroad era developed so rapidly, of neces. sity Iowa would have used some public financing plan such as Ohio's, due to the breakdown of the system of private financing and construction.

${ }^{36}$ See the Journal of the Illinois State Historical Socioty, X, 29-36.
} 
facturing center, but retail trade was a much more important factor in those early days. Early Chicago was not far removed, either in point of time or economic development, from the Indian trading post of old Fort Dearborn.

Canals and improvements on navigable streams in those days were left to Mother Nature, rather than placed under the control of a paternal government. Improved roads, however, were absolutely necessary to meet the farm-to-market requirements, and in the absence of other surfacing materials, plank roads, for the time being, seemed to meet the demands of the existing situation.

Even before the Illinois general plank road act of 1849 , special charter companies had begun the work of construction. In 1848 the "Southwestern Road" out of Chicago was commenced and by 1850 sixteen miles had been completed. Soon thereafter it extended downstate for sixty miles with numerous branch lines. Similar roads to the west and northwest tapped nearby trade areas, thus affecting a stabilization of both retail and wholesale trade for the growing city. Many miles of plank roads radiated from Chicago and other centers, but roads actually completed were as nothing to the plans conceived for main-line highways across the state with feeding lines to almost every county seat.

In many eases these plank roads were extremely profitable, not alone in Illinois, but in all the states where they were tried. Stockholders reaped handsome returns during the few years in which they flourished as the main arteries of travel, and in lesser measure, as they later supplemented the early railroads. The areas adjacent to these construction projects benefited as did the territories through which railroads were built in the second half of the century. As is to be expected, the financing of the plank road companies was obtained in the main from the eitizens who expected to gain direct benefits, and from the communities to which the road was to bring traffic. The eapital invested in each of these companies ranged from a few thousand dollars to a probable high of $\$ 100,000$. Earnings of $10 \%$ to $40 \%$ were not unusual, and, had the railroad not come so soon, the plank roads in 
eonjunction with the stage lines would have resulted in founding fortunes like those of the early railroad builders.

The early success and prosperity of the planks roads, however, was deceptive, for the rapidity of their rise was often equalled only by the speed of their decline. In New York state, by 1868 , only seventeen companies remained in existance, and then only operated as turnpike companies. By 1871, three years later, but ten miles of turnpike still functioned in the whole of that state.

A chief obstacle to the permanence of all the plank roads was that though they were ideal for the horse drawn traffie of the day when first constructed, they deteriorated more rapidly than had been anticipated; their life was only from five to seven years, instead of the estimated ten to fifteen. Then too, plank roads when in disrepair were a real danger to traffic, and, realizing the impossibility of building up the necessary reserves for replacement, the companies paid out their income in salaries and dividends. Thus while the communities which the roads served were greatly benefited, the stockholders suffered heavy losses after the first fruits had been gathered.

Perhaps the spirits of stockholders in the old plank roads chuckle a bit as they sit on the banks of the River Styx and learn that the railroads which put them out of business are meeting reverses similar to those which they experienced, because of the threats of other types of highway construction and travel.

\section{Plank Road Legislation in Iowa}

The territorial legislature of Iowa had passed many acts for the laying out of "territorial roads," but none provided for the construction of a planked system of wooden highways. The establishment of a system of "state" roads by the First General Assembly did not provide for or envisage plank road construction either. That had to wait for the Second General Assembly of Iowa.

At the second session of the General Assembly, held in the new stone Capitol at Iowa City on the banks of the Iowa River-the building which loyal students and alumni of the 
State 'University of Iowa now lovingly call "The Old Capitol" - a group of far-sighted pioneers in industry, James Weed of Muscatine County, John Culbertson of Cedar County, William Abbey of Linn County, and Thomas Way of Benton County received the first grant of authority to lay out a graded road from Bloomington (now Museatine) by way of Tipton in Cedar County, to the "County Seat of Benton," then undetermined. Just a week later the legislature provided for an April election to determine the location of the county seat of Benton County.

This was the first graded or plank road project authorized by the legislature of the young state. This was also Iowa's introduction to a brief experience with the Turnpike systemthe operation and maintenance of highways by a private company for profit-and the legislators were most careful to guard the interests of the citizenry against capitalistic aggression.

The lawmakers went into great detail in this chapter. The grade was to be not less than thirty feet in width, and work was to be commenced within six months from the taking effect of the act. The owners of the real estate through which the roadway was laid out, even if they refused a free consent, could not thereby delay construction, but after notice given, the damages or benefits were to be finally determined by a board of appraisers. Thirty days' notice to non-resident owners was to be given by publication, and they then had twenty days within which to protect their rights. Toll houses and gates were provided for, and the commissioners of the counties through which the road was laid out were authorized to determine the tolls to be charged. Schedules of rates were to be posted at the toll house or gate, and those who used the road were required to pay such charges, a failure to do so rendering them liable for double damages and all costs of the suit. I feel that there were all too few lawyers in this session of the assembly, else provision would have been made for the fees of the plaintiff's attorney. Obstructing, injuring or damaging the roads, gates, or toll houses would subject the culprit to fine or imprisonment at the discretion of the court. 
The organizers were granted a period of twenty years within which to enjoy the fruits of their labors, with the proviso that, at the expiration of that period, if a joint convention of the commissioners of the several counties determined that the builders had not received reimbursement for the expense of construction and maintenance and a reasonable return on their investment, the right to collect tolls might be extended. Thus early did Iowa decide to control its public utilities.

Of particular interest to us is the provision that in case the organizers should at any time "deem it necessary for the interest of the public" they might construct a plank track, "not less than eight feet in width," and receive such additional toll as the county commissioners might determine.

The organizers were required to form themselves into a company under the terms of an "Act to authorize general incorporation." At the expiration of the term of the grant, the road should be deemed a public highway under the control of the county commissioners. ${ }^{17}$

Now consider, if you please, the almost foolhardy business courage of these men if a plank road or a graded toll road was to be built. The distance between Muscatine and Tipton was thirty miles, and sixty-four miles between Tipton and the "County Seat of Benton County," which we may assume to have been Vinton, for so it was when that county was organized in 1849. Ninty-four miles was not the two-hour drive we find it today, but the slow, patient, down-dale and up-hill, through this stream and around that swamp, ox-cart driving which George C. Duffield described and which most of our grandparents experienced when they eame to Iowa.

The population of the counties to be travelled by this highway in 1849 were as follows:

\begin{tabular}{lr} 
Muscatine & 4516 \\
Cedar & 3138 \\
\hline Linn & 4762 \\
\hline Benton & 312 \\
\hline & 12728
\end{tabular}

${ }^{17}$ Acts of the Second General Assembly of Iowa, Chap. 33, Approved January $8,1849$. 
The population of the entire state was only 116,454, and but 39 counties in the census of 1849 reported any white eitizens. It is true, however, that by the following year those four counties showed the handsome total of 15,738 , while ten additional counties reported inhabitants in the census of 1850 .

Evidently these ambitious promoters found, in the language of the period, that they had "bit off more than they could chew," for on February 4, 1851, the Third General Assembly amended the previous Act by requiring a sixteen foot grade only, and authorizing collection of toll when but ten miles of the road had been completed. James Weed seems to have found that the way of the promoter, as well as that of the plank road builder, was not alway smooth. ${ }^{18}$

A week after the first plank road was authorized by the legislature, a group of citizens from Lee County under the leadership of William Brownell was granted authority to construct a plank road on the ten-mile stretch between Montrose and Keokuk with a grade forty feet wide and a plank track eight feet wide. This franchise was to continue for a period of twenty-five years. Evidently these Lee County eitizens did not have the confidence in the liberality of the county commissioners manifested by James Weed and his associates, for in section three of the act the following toll rates were set out: $:^{19}$

carriage, wagon, eart or sleigh drawn

by two horses, oxen or mules each additional animal

$2 \frac{1}{2} \&$ per mile vehicle drawn by one horse, ox or mule horse and rider $1 c$ per mile

$2 \phi$ per mile 16 per mile each head of horses, oxen, mules or eattle led or driven each sheep, goat, or hog merchandise (not including furniture of immigrants)

1c per mile $1 / 2 \&$ per mile

26 per mile

18 Acts of the Third General Assembly, 1851. Chan. 44. 1849 .

19 Acts of the Second General Assembly, 1849, Chap. 96, Approved January 15, 
The grant to William Brownell for the Montrose-Keokuk plank road is the only one which sets out the rate of toll charges, the county commissioners being given the right to set the charges in all other grants. In the code of 1851 the legislature turned over to the various county courts authority to grant licenses for a period of twenty years and to fix the toll charges on any macadamized or plank road or other improvement of like character. ${ }^{20}$

Provisions were also made in the same chapter for toll eharges on ferries and bridges. ${ }^{21}$

During the four-year period between January 8, 1849 and January 15, 1853, when the last plank road company was authorized to construet a wooden highway, fourteen different groups of individuals and companies were granted rights to construct graded, plank toll roads and to collect tolls for their use, providing for the construction of almost six hundred miles of highway. In order of their adoption, the roads provided for were as follows:

1. Bloomington (now Muscatine), to County seat of Benton County, via Tipton. Approved January 8, 1849

94 Miles

2. Montrose to Keokuk. Approved January 15,1849

10 Miles

3. Burlington to Mt. Pleasant via Middleton and New London. Approved January 15, $1849 .{ }^{22}$

28 Miles

4. Burlington to Mt. Pleasant. Approved December 18,1850

28 Miles

5. Museatine to Oskaloosa via Washington Approved January 18, 1851

104 Miles

6. Burlington to Toolsborough. Approved January 21, 1851

28 Miles

7. Keokuk to Birmingham via Charleston. Approved February 4, 1851

69 Miles

\footnotetext{
1246.

${ }^{20}$ Code of 1851 , sec. $735,738,748,750$; see also Code of 1860 , sec. 1223, 1226 , ${ }^{21}$ See Iowa Code of 1851, Title 9; Code of 1860, Title 11, Chap. 54. ${ }^{22}$ Acts of the Sccond General Assembly, Chaps, 33, 96, 131.
} 
8. Burlington into Louisa County. Approved February 4, 1851

9. Muscatine to Iowa City. Approved February 4,1851

40 Miles

10. Mt. Pleasant to Trenton to Brighton via Deedsville. Approved February 5, 1851

33 Miles

11. Ft. Madison to West Point to Salem. Approved February 5, 1851.

25 Miles

12. Port Louisa to Virginia Grove via Wapello. Approved February 5, 1851.

25 Miles

13. Ottumwa to Libertyville. Approved February $5,1851 .^{23}$

24 Miles

14. Mt. Pleasant to Fairfield. Approved January $18,1853{ }^{42}$

25 Miles

This impressive list is a blue print of the visions of hopeful, ambitious, and speculative Iowans rather than a record of actual plank roads constructed in the state. And even in their optimistic visions these early promoters of the Turnpike System of privately operated highways salted their hopes with practicality. Two of the fourteen companies formed, the Bloomington-County Seat of Benton County road and the first Burlington-Mount Pleasant route, provided for the construction of plank highways only as an afterthought it seems, since only in a short paragraph tucked at the close of the statutes was it provided that a plank road might be built, "if the said_—and his associates shall at any time deem it necessary for the interest of the public ...." We may be sure that they "deemed", the public's interests included their own as well. There is no record of the first project ever completing a mile of plank road, and the second company later reorganized and received another charter as the Burlington Mount Pleasant Plank Road Company, after the plank road idea really appeared feasible to Wm. F. Coolbaugh and his associates. The Iowa statutes abound in ambiguities such as that appearing in the grant to the Montrose-Keokuk company, which was authorized to construct a " 'graded and

${ }^{23}$ Acts of the Third General Assembly. Chaps. 1, 13, 24, 35, 41, 48, 59, 64, 65, 78.

${ }^{24}$ Acts of the Fourth General Assembly, Chap. 22. 
planik" road; the Museatine to Oskaloosa and the Muscatine to Iowa City routes were authorized to be eonstructed as a graded or plank road. It is probable that all three grants meant a plank road and a plank road only, though since James Weed was associated with the second Museatine route, and possibly the first, it may be assumed that the charters were so drawn as to permit the companies to benefit by his experience in the Bloomington to Tipton road.

On the whole the Iowa statutes were very loosely drawn, presenting a sharp contrast in this respect to the careful specifications drawn by the neighboring states for the finaneing, organization, construction, and operation of plank road companies, in Wisconsin and Minnesota for example. Apparently no effort was made to eliminate speculation in the projection of plank highways, or for insuring the responsibility of the companies for work undertaken. The lawmakers appear to have assumed their duties fulfilled if the applicant company was granted the use of a right of way requisite for the route it wished to follow, and if suitable provisions were made for the protection of the property owners in the path of the proposed highway in their rights and the value of their property. It was this limited concern of the Iowa lawmakers to such matters that gave a uniformity to the legislation despite the fact that Iowa did not enact a general plank road law during this period, as was done in the other adjacent states.

\section{Plank Road Construction in Iowa}

While these fourteen companies were authorized by Iowa legislatures to construct approximately six hundred miles of turnpikes or plank roads, probably no more than fifty miles were ever actually laid. ${ }^{25}$

Enthusiasts, however, dreamed of a network of improved or plank roads between the principal communities of the State, but, for the most part, these hopes ended as dreams, as did many of the road projects accepted by the legislature.

It is safe to conclude that the interests of the enthusiasts in highway construction were not altogether altruistic, to

${ }^{25}$ For a survey of the construction activities of the 14 authorized plank roads see Palimpsest, XV, 307-18. 
judge by the accounts of organization meetings held all over the southeastern part of the state, the contributions secured from counties and munieipalities, and the grandiose plans which in almost, if not every, instance failed, carrying with them the investors' money.

Stock salesmen, then as now, were efficient and numerous and, perhaps, as successful proportionately as in the memorable days before October 29, 1929. The newspaper accounts of these organization meetings with the attendant rivalry between groups of organizers and contending eities and counties reminds one of the days of pioneer railroad construction farther west, when the first transeontinental lines were building, and every little community acclaimed to railroad promoters the superlative advantages of its site.

The life span of all these fourteen roads was short, in fact only a scant few ever were constructed. Initial obstacles, expense of construetion, the financial and engineering diffieulties incident to the bridging of the rivers, the maintenance costs, and the small population served by many, seem to have sounded the death knell of all but the most hardy of these ambitious projects.

The Burlington-Mount Pleasant road was probably the best known of all the roads, and was the only one actually completed from terminal to terminal. This road, as a quotation from Judge James D. Smyth indicates, was in operation for several uneasy years.

The Burlington-Louisa County road was in part constructed with some of the requisite bridges built, but it, alas, failed of ultimate completion.

Near Keokuk, whose boastful citizens have asserted for many years Lee County's independence from the State of Iowa, the Montrose-Keokuk plank road was partially constructed along the Des Moines Rapids of the Mississippi, while the road to the northwest, still reminiscently referred to by older citizens as "The Slab," was planked for a distance of twelve or fifteen miles, complete with toll houses and toll gates. It, too, failed of profitable operation and ultimately came into the possession of Lee County. 
The methods of construction as gleaned from the press of that day and the memories of older citizens, who in their youth saw these roads, indicate that the usual construction after grading was completed was as follows: stringers hewed out of black walnut, six inches square, were laid lengthwise of and imbedded in the earthen grade, aeross them were placed oak or pine planks eight feet long, two or three inches thick, and as wide as possible. The timbers were cut from the surrounding forest and were, of course, unseasoned. Later the planks were fastened with hand wrought spikes, or pegged to the stringers. The earth was packed tightly around the stringers and between the planks to make as firm a support for the planking as possible and also to prevent decay. Knowing the present seareity and value of black walnut, it makes me eringe to think of that quality and type of wood being used for such a purpose.

The Honorable James D. Smyth of Burlington, who has served on the district bench of Iowa for forty-seven years, and who came to Iowa as a boy in 1857 , saw some of these plank roads around Burlington as a youth, and tells me that the Burlington-Mount Pleasant highway which was constructed in the early fifties was one of the improvements to which that town pointed with justifiable eivic pride. He writes:

There was for some time after my family eame here a plank road from Burlington to Mount Pleasant, which you indicate in your list as No. 3, which was considered a very valuable publie improvement. I remember being told by a eivil engineer of that period, who was considered very eompetent in his line of work, that this road was constructed of white oak planks three inches thick and of high quality, and that the material employed in the road of about 25 miles, if offered for sale when there began to be a demand for high elass lumber, would have brought enough in the market to have built a railroad between the two places named. At the time of the construetion of the road, however, such means of transportation as were available had to be employed and the abundance of high quality timber in the surrounding country naturally indicated its use for all-weather road.

The newspapers of that day state that a fair estimate of of the cost of construction was about $\$ 2600$ per mile, and the more sanguine promoters in the eastern states put the figure 
at $\$ 1500$, in accordance with the requirements of stock subseription that had to be paid before construction was permitted.

Today, as we see what man's genius has done for our motorized highways, we cannot help but wonder whether those dreams of ninety years ago might have been attained if "Puffing Bill," the "Rocket," and steam railroad construction had not come into existance until after the War of Rebellion. At all events, the child of George Stephenson's genius quickly destroyed a most interesting economic concept.

\section{Plank Roads in the Courts}

During the heyday of development, this new economic and social concept, the Plank Road, resulted in considerable litigation over construction, operation, maintenance, and financing in all the states. Much of the litigation involved attempts to collect payments on stock from subscribers who had pledged their eredit not wisely, but too well. The opinions in these early cases clearly show the friendly attitude of the courts toward the new venture, and that a failure to strictly comply with the terms of the acts was not permitted to release the liability of the subseribers. ${ }^{26}$

The courts also held that the failure to designate the precise route and termini was not so important a deviation from the act as to allow a subseriber to eseape his payments. (Western Plank Road Co.vs Stockton, 7 Indiana 500.)

The rights of adjacent property owners, of turnpike companies already using the highways, and of the municipal corporations effected by the construction of plank roads, received very careful consideration by the courts.

In an early New York case in which the opinion was written by Judge Gridley in 1850, it was held that the use of public highways by plank road companies did not take away their public character. Their use for plank roads and the collection of tolls was no different from that by turnpike companies.

${ }^{26}$ See Covington, Coal Creek \& Jackson Plank Road Co. vs. Moore, 3 Indiana 510; Stoops vs. Greensburgh \& Brookfield Plank Road Co., 10 Indiana 47; Dexter \& Mason Plank Road Co., vs. Millerd, 3 Michigan 91 (1854); Pettibone vs. McGraw, 6 Michigan 440 (1859); Nichols vs. Burlington Plank Road Co., 4 G. Greene 42 (Iowa, 1853). 
The plank road company, like the turnpike company, was held to be an ageney authorized by the state to improve and maintain the public highways, and, instead of being paid a lump sum by the county or state, received its compensation from the users. The rights of the company in the highway were set out by the learned judge and were likened to the right of a municipality to grade or improve a public road. The constitutionality of the act was expressly confirmed. Benedict vs. Goit, 3 Barb. 459, New York, 1850.)

An early case in Michigan involved the alleged obstruction of a publie highway by the Detroit and Erin Road Company through the construction of a plank road and toll houses and toll gates over and across the highway. The ineorporation of that particular company had authorized the construction of the plank road from Detroit to the township of Erin, and particularly permitted them to use the highway between the two places. The conflict between the general law and the plank road law was clear and the court held that the expense previously put upon the roadway which was to be utilized by the company should be returned to the municipality. In McKay vs. Detroit \& Erin Plank Road Co., (2 Michigan 139, 1851), the court held:

It would seem reasonable where the legislature authorized highways to be used for the construction of plank roads, that the people upon whom was east the burden of their construction should be paid such sums as may be deemed just by the plank road company to whose benefit they enure. The elearing, grubbing and grading of the road constitutes an important item in the construetion of plank roads, and it is but right that when incorporated companies avail themselves of the use of highways constructed at the expense of the public, that they should restore to the public the sum expended for their benefit or such other sum as may be reasonable, to the end that the amount thus restored may be either used for the repair of highways in their respective townships or in the laying out of new ones as provided in the general plank road law.

Then as now, litigious individuals were prone to assert alleged rights perhaps more to the resultant profit of their attorneys than themselves. A ease involving a tender of one cent as toll by a Mr. Fisher received the consideration of the 
Supreme Court of Michigan in 1853. (Detroit \& Howell Plank Road Co. vs. Fisher, 4 Michigan 38, 1853). The facts established were:

On the 13th of June, 1853, the defendant was traveling on the said road from Detroit west, with a one-horse wagon, and at the first gate on said road, Gate No. 1, three-fourths of a mile from the eastern end of the road, tendered the gate-keeper one cent, and elaimed the right to pass the gate. The keeper inquired how far he intended to travel on said road, but defendant declined telling, and insisted on his right to pass on payment of the toll for one mile, being all that he had then travelel on the road. Thereupon, the keeper demanded toll of him to the next gate, and ordered him not to pass the gate until he paid it. But defendant refused to pay any toll but the one cent already tendered, and passed the gate against the express order of the gate-keeper, but without any actual foree, the gate being open, and the keeper offering no personal resistance.

The Michigan court held the rule that plank road companies were authorized to erect gates and exact toll whenever they had completed the road or five consecutive miles thereof, even though there had not been a strict compliance with the terms of the act; that the company had the right to exact toll in advance from any person who was actually traveling upon the road, and on his refusal to state how far he proposed to go on the road, the company could exact toll for the distance to the next toll gate; and that any violation of this rule constituted an offense under the terms of the Act.

The last phase of plank road litigation involves the forfeiture of franchises because of failure to maintain the improvements in a proper state of repair.

In an early Indiana case (Covington, Coal Creek \& Jackson Plank Road Co. vs. Van Sickle, 18 Indiana 242, 1862), an action in Quo Warranto was brought to determine the right of the Covington, Coal Creek \& Jackson Plank Road Company to continue to exercise its corporate franchise, the allegation being that it had failed to keep its roadway in repair for the period specified in the various acts. By reason of an error in pleading, the court did not pass squarely on the question, but the opinion shows a friendly feeling on the part of the courts 
for these enterprises so important to the development of the country.

It seems strange that in Iowa the only reported case involving a toll or plank road company which has come to my attention is Nichols vs. Burlington Plank Road Company, decided in 1853, in which Justice Greene determined the liability of a subseriber of stock to make payments in aecordance with his subscription agreement.

Perhaps the early nisi prius court records of counties in southeastern Iowa might disclose litigation, but such eases seemingly did not reach the Supreme Court of Iowa.

\section{The End of an ERA}

The notable feature of this era of graded and plank roads was the rapid mushroom like development of the idea; all the fourteen companies in Iowa were chartered within the relatively short space of a four year period. It was the misfortune of these road projects, however, to come quickly into competition with the railroads, actual and dreamed of, which spanned Iowa. The expense incident to grading and planking of turnpikes coupled with the ever-present danger that a railroad might parallel the highway was a serious deterrent. The financial and civic interest in plank roads was unable to withstand the more compelling interest in subsidized railroad construction which would connect the newer regions not only with the Mississippi River, which was all the plank roads could do, but also with Chicago, Pittsburgh, Cleveland, and the Atlantic seaboard. The final construction of railroads in and across Iowa marked the end of the Plank Road.

By 1856 the Mississippi and Missouri Railroad had established a railhead at Iowa City, from which settlers took off into the blue. Eleven years later a rail connection had been established between Council Bluffs and the Mississippi, two years later the Chicago, Rock Island \& Pacific Railroad also had a terminus on the Missouri; at the turn of the century, the peak of railroad construction in Iowa had been reached. But long before, the Plank Road in Iowa had been forgotten.

Besides the eompetition from the railroad, though perhaps 
it is because I live in a cement manufacturing center which early enjoyed the benefits of hard surfaced roads, I wonder whether the lack of highly mechanized systems of construction and satisfactory surfacing materials might not have been a contributing eause for the abandonment of these early schemes for road improvement.

In 1904, fifty years after the era of Plank Roads in Iowa, only $7.14 \%$ of the nation's highways were improved. Iowa and the nation had to await the demand of a motorized civilization before the hopes of James Weed, John Culbertson, William Abbey, Thomas Way, and the rest of those pioneers in highway construction, had their fruition in a maze of improved highways, many of which follow the very trails those pioneers blazed.

Those old roads upon which our pioneer forebears journeyed are gone. The ruts and stones over which they bumped with stoic patience are today smooth ribbons of eonerete and only here and there in some bit of virgin timber do we find the deep worn ruts along which ox teams and stages brought civilization to the west. ${ }^{27}$ In very truth, Transportation is. Civilization.

\section{THE PROPOSED KEOKUK-FORT DES MOINES PLANK ROAD}

The main trunk-if I may so term it-would run through the flourishing towns along the ridge, having lateral roads or branches, ranging in length from three to ten miles, to the various beautiful little towns on the banks of the Des Moines and Skunk Rivers.

Every farmer within ten miles of the road should be willing to furnish a few thousand feet of lumber, or to take his team and grade a section of the road and take the amount in stock. ... The investment would be a very profitable one, such roads having generally paid dividends ranging from 25 to 50 per cent.—quoted from the "Whig and Register"' (Keokuk papers) by the Iowa Star (Fort Des Moines), Mareh 1, 1850.

\footnotetext{
${ }^{27}$ A few miles southwest of Mason City, in Owen's Grove, early settled by Cerro Gordo County pioneers, one can still see the ruts of the route taken by stages and private teams from Waterloo and Rockford to Mason City, the route which brought settlers to the latter city eighty-five years ago.
} 
Copyright of Annals of Iowa is the property of State of Iowa, by \& through the State Historical Society of Iowa and its content may not be copied or emailed to multiple sites or posted to a listserv without the copyright holder's express written permission. However, users may print, download, or email articles for individual use. 